\title{
Woody Plant-Herbivore Interactions in Semi-Arid Savanna Ecosystems
}

\author{
Allan Sebata \\ Additional information is available at the end of the chapter
}

http://dx.doi.org/10.5772/48400

\section{Introduction}

Savannas cover more than ten percent of the world's land surface and more than fifty percent of Africa, providing browse to millions of mammalian herbivores (Scogings \& Mopipi, 2008). Although herbivory is a major driver of ecosystem functioning in semi-arid African savannas plant-herbivore interactions are poorly understood (Skarpe, 1992; Scholes, 1997; Scogings, 2003). African savannas and large herbivores coevolved, with woody plants developing defences against herbivory (Du Toit, 2003). The herbivores have in turn evolved counter measures against the plant defences. Large herbivores counteract the effects of plant defence by selective foraging, fragmentation of intact plant tissues, microbial fermentation and expanded guts for microbial breakdown, whereas plants protect themselves through morphological, structural and chemical adaptations (Borchard et al., 2011). African savanna ecosystems under heavy browsing have few hardy woody species that are resistant to or are defended against defoliation. Cornell and Hawkins (2003) suggested that plants acquire better defences with time which herbivores in turn learn to partly or fully overcome. Hartley \& Jones (1997) found woody plants to be able to live in environments where herbivores were common because of their ability to resist or recover from intense herbivore pressure. The varying defences that plants exhibit is a reflection of the diversity of herbivores and abiotic conditions. Plant defences exert selective pressure on mammalian herbivores, with the result that many have developed mouthparts and digestive systems that facilitate the use of particular plant types. The chemical defences of terrestrial plants reflects in part the biochemical evolution of early land plants and the problems those plants encountered.

A number of plant defence theories have been advanced to explain why some plants are better defended than others. For example, the optimal defence hypothesis focuses on how defensive needs of plants leads to the evolution of chemical defences, with the cost of that defence maximizing fitness. This chapter will discuss the effects of herbivory on woody 
plants, show how the plants respond to herbivory and explore herbivore adaptations to plant defences. I will also discuss the woody plant-herbivore interactions in terms of browse instantaneous intake rates and explain how shoot morphology influences herbivory.

\section{Effects of herbivory on woody plants}

Herbivory can negatively through instantaneous death (Belsky, 1986) or positively through increased growth and competitive ability (McNaughton, 1979) influence plant fitness. The effect of herbivory on woody plants depend on the intensity and frequency of damage, plant phenological stage and resource relationships at the time of herbivory, plant tissues removed, competition with non-browsed species and the characteristics of the plant species (Maschinski \& Whitham, 1989). Damage to individual woody plant branches negatively affects growth and reproduction of those branches but leads to compensatory growth in non damaged branches (Du Toit et al., 1990). Many woody species in the semi-arid savanna are able to resprout following herbivory. For example, Acacia karroo has the ability to coppice strongly following defoliation (Teague \& Walker, 1988). Herbivory stimulates shoot production in mature Acacia trees (Dangerfield \& Modukanele, 1996) and root growth in Faidherbia albida (Dube et al., 2009), while negatively affecting Acacia seedling growth (Walker, 1985). The resprouting of woody plants after damage by herbivores depends on their ability to use stored nutrient reserves and on the buds that escaped herbivory and can be activated for new growth. Woody plants differ in their ability to recover after herbivory with resprouting being influenced by the rate of regrowth of leaves and shoots. In a study to compare the compensatory abilities of three Acacia species, Acacia karroo fully compensated while Acacia nilotica overcompensated with Acacia rehmanniana under-compensating lost biomass (See Figure 1).

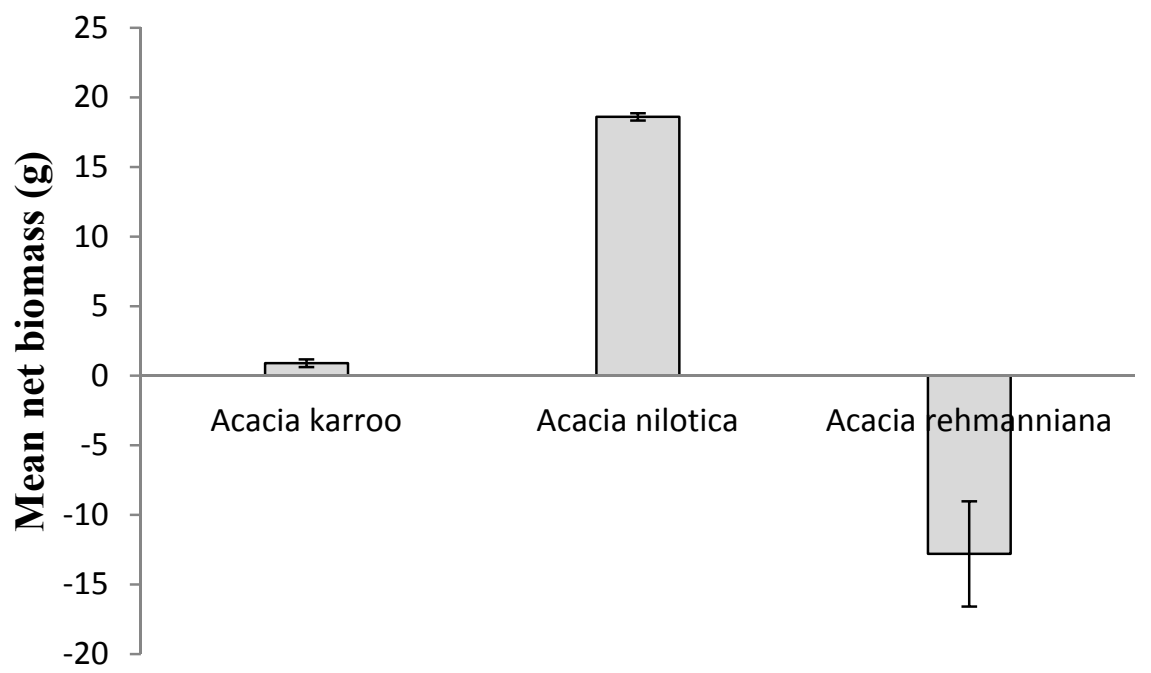

Figure 1. Mean $( \pm \mathrm{SE})$ net biomass of Acacia karoo, Acacia nilotica and Acacia rehmanniana following shoot clipping in a semi-arid savanna. Source: Tsumele et al., 2009 
Under-compensation of lost biomass may prevent further browsing while full- or overcompensation may increase forage availability and quality and thus initiate further browsing (Bowyer \& Bowyer, 1997). Dube et al. (2009) also reported A. nilotica as more tolerant to herbivory than Acacia nigrescens and Faidherbia albida. Resprouting of shoots is intense following herbivory early in the growth season as plants have more time to recover before the end of the growth season. Shoot regrowth depends on the amount of carbohydrates that can be mobilized through photosynthesis or in carbohydrate reserves (Page \& Whitham, 1987). Regrowth following defoliation is positively correlated with the carbohydrate status of the plant (Trlica \& Singh, 1979) and resilience to defoliation depends on the rapidity with which reserves are restored (Dahl \& Hyder, 1977). Compensatory regrowth of woody plants following herbivory occurs when nutrient and water resources are not limiting (Rosenthal \& Kotanen, 1994). In the early growth season nutrient and water resources are abundant allowing plants to over-compensate lost biomass while late in the growth season the resources are inadequate leading to undercompensation (See Figure 2).

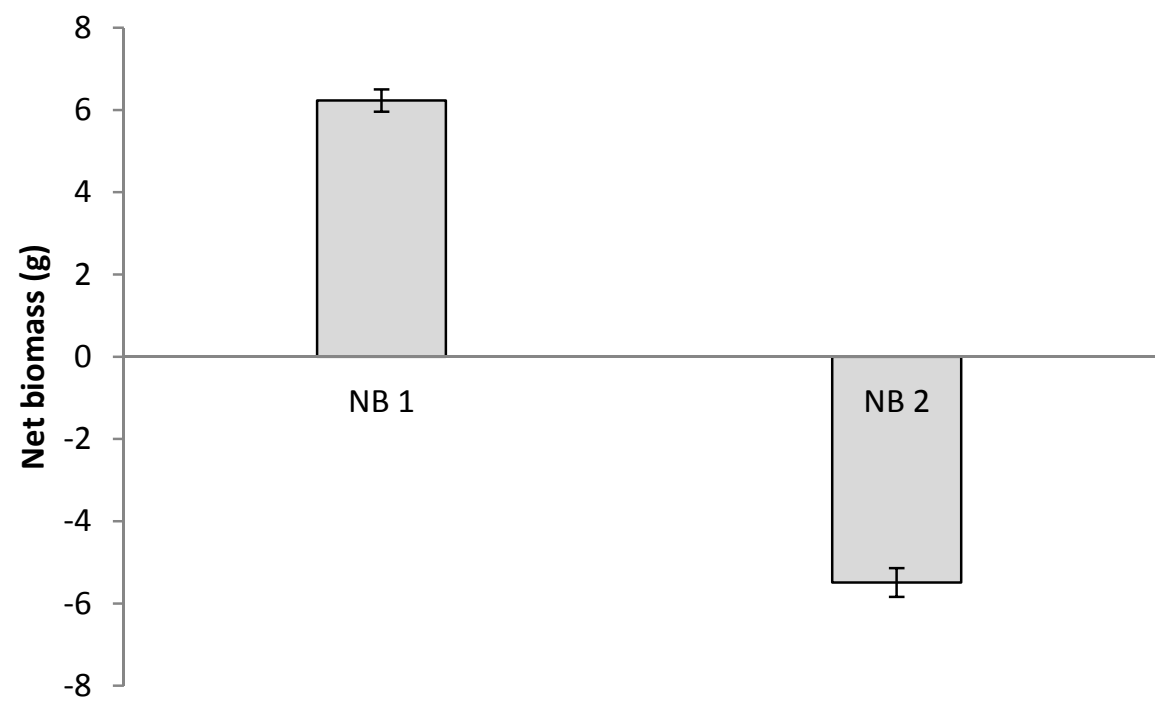

Figure 2. Mean $( \pm \mathrm{SE})$ net biomass of Grewia monticola following shoot clipping during early growth season (NB 1) and late growth season (NB 2) in a semi-arid savanna. Source: Sebata et al., 2009

Herbivory during the early growth season coincides with nutrient flush enabling plants to benefit from energy mobilized from stored reserves. Scogings (2003) found defoliation during the early growth season to stimulate plant growth while growth of once-defoliated trees was not elevated above that of undefoliated trees when defoliation took place during the dormant season. Teague \& Walker (1988) reported Acacia karroo as very sensitive to defoliation when carbohydrates reserves were at their lowest but very tolerant when reserves were high. Compensatory growth occurs when part of the photosynthetic material 
of a plant is removed resulting in more water and nutrients becoming available to the remaining photosynthetic components to increase their growth performance. Defoliation modifies the balance between growth promoting and inhibiting hormones in the plant resulting in various internal changes, such as increased photosynthesis, reduced rate of leaf senescence, changes in metabolite allocation and increased cell division and elongation which all contribute to increased growth (McNaughton, 1979; Teague \& Walker, 1988). The growth following defoliation results in leaf replacement within weeks and then elevated levels of growth continue thereafter for more than a year, resulting in very large increases in leaf and shoot production compared to undefoliated plants (Teague \& Walker, 1988). Compensatory regrowth following herbivory is considered an evolutionary response to herbivory (McNaughton, 1979). Crawley (1983) studied the implications of plant compensation at an ecosystem level and concluded that compensation following defoliation can improve ecosystem stability and increase the abundance of herbivores. Teague \& Walker (1988) argued that compensation would benefit the plant only if herbivores fed on the plant intermittently or for a limited time each year, with the plants able to compensate once feeding has stopped. Strong plant compensatory growth cannot occur under continuous herbivore foraging.

Removal of the main shoots during browsing reduces apical dominance leading to the development of lateral shoots from activated dormant buds. Twig browsing in woody species can remove significant proportions of meristems resulting in fewer shoots in the following growth season (Bergstrom et al., 2000). The remaining shoots will experience less competition and thus grow larger and have higher nutrient concentrations than those on undamaged trees (Bergstrom et al., 2000; Rooke et al., 2004). Teague \& Walker (1988) reported the increases in leaf and shoot of $A$. karroo plants following defoliation as due to the large increases of relatively few dominant shoots in the upper canopy. Danell et al. (1994) found leaf stripping of trees during the growth season to result in an increase in the number of shoots and a decrease in shoot size the following season. Some woody plants respond to severe defoliation from intensive browsing by producing many sprouts from basal shoots from the lower part of the stem enhancing the persistence of the plant (Bond \& Midgley, 2001). This increases the plant's photosynthetic capability and creates the potential for increased juvenile recruitment. Resprouting shoots have been reported to have reduced defence compounds as a result of resources being allocated for fast growth at the expense of defence or the breakdown of existing defence compounds for use in growth (Coley et al., 1985).

Browsing reduces tree density, canopy cover and canopy diameter (Noumi et al., 2010) and affects tree regeneration (Mekuria et al., 1999). Fornara \& du Toit (2008) reported Acacia trees at lightly browsed sites as having wider canopies and branches with longer internodes than trees at heavily browsed sites. The short internodes in the heavily browsed Acacia trees resulted in reduced canopy volume and increased side-branching on browsed shoots due to suppression of apical dominance (Du Toit et al., 1990). Browsing by megaherbivores e.g. African elephants (Loxodonta africana) reduces tree height resulting in a larger proportion of shoots and leaves becoming available within the browsing height of most terrestrial herbivores (Makhabu et al., 2006). Makhabu et al. (2006) reported impala (Aepyceros 
melampus) and greater kudu (Tragelaphus strepsiceros) as benefiting from the impacts of elephants in converting tall trees to short trees. More shoots were produced in heights reachable by both impala and kudu. Other studies have reported browsed trees as producing shoots with increased biomass per shoot (Bergström \& Danell, 1987), increased nitrogen concentration and decreased concentration of secondary compounds like condensed tannins (Du Toit et al., 1990) compared with unbrowsed individuals. Eland at high densities prevent the recruitment of Combretum apiculatum from the $2.6-5.5 \mathrm{~m}$ height class to the $>5.6 \mathrm{~m}$ height class (see Figure 3 ).

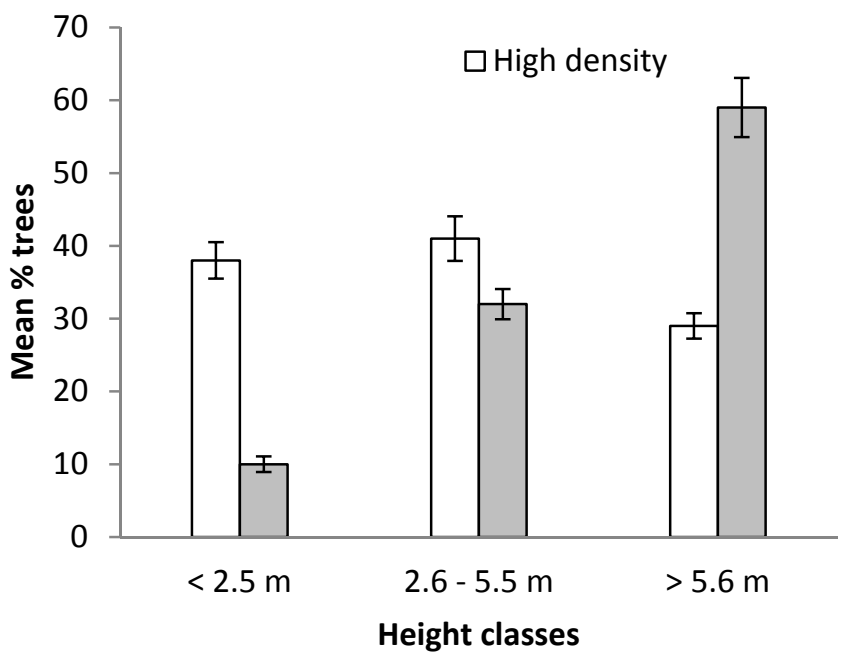

Figure 3. Mean $( \pm \mathrm{SE})$ per cent of Combretum apiculatum trees in three height classes in relation to eland density. Source: Nyengera \& Sebata 2009.

Shoot regrowths after defoliation have higher crude protein, phosphorus and biomass leading to repeated herbivory (Makhabu \& Skarpe, 2006). Repeated browsing by megaherbivores such as the African elephant (Loxodonta africana) leads to the formation of low, intensely coppiced trees or stands of trees with high production of preferred browse (Makhabu et al., 2006). Rebrowsing means that the targeted trees suffer repeated damage and may eventually die or suffer reduced competitive ability relative to other woody plants (Skarpe \& Hester, 2008). Heavy browsing by giraffe reduces tree growth rates increasing their susceptibility to drought (Birkett \& Stevens-Wood, 2005). Fornara \& du Toit (2008) reported high plant compensatory growth abilities of Acacia nigrescens as important for its persistence under heavy browsing in the Kruger National Park, South Africa. Herbivores also restrict the growth and the survival of young trees (Mwalyosi, 1990). Noumi et al. (2010) reported browsing as improving the regeneration of Acacia tortilis trees through the recruitment of new individuals. Skarpe (1990) argued that browsing accelerates tree growth in semi-arid savanna through reducing competition for moisture from herbaceous plants. 
Herbivory may interfere with sexual reproduction in plants, either indirectly by changing physiology and allocation of resources, or directly by consumption of flower buds during the dormant season and flowers and fruits during the growth season (Skarpe \& Hester, 2008; Fornara \& du Toit, 2008). Herbivory results in plants allocating more resources to vegetative growth at the expense of sexual reproduction favouring species that reproduce vegetatively (Crawley, 1997). Goheen et al. (2007) reported herbivory as negatively affecting Acacia drepanolobium reproduction in an eastern African savanna.

\section{Woody plant response to herbivory}

Woody plants have evolved different strategies to reduce the negative effects of herbivory on their fitness (Rosenthal \& Kotanen, 1994; Strauss \& Agrawal, 1999). The strategies employed by plants to cope with herbivory can be classed into tolerance and avoidance mechanisms.

Tolerance strategies minimise the impacts of the damage (Hanley et al., 2007), with tolerant plants being generally palatable to the herbivores (Skarpe \& Hester, 2008). Woody plants show tolerance to herbivory through morphological means such as quick replacement of lost leaves and shoots from protected meristems or through physiological processes such as compensatory photosynthesis and high and flexible rates of nutrient absorption (Hester et al., 2006). Re-sprouts have higher photosynthetic rates than older leaves. Teague (1989) reported Acacia karroo as relying on deep rooting, strong reserves and rapid growth to counter herbivory. Tolerance in plants is assumed to have little direct effect on herbivore fitness and is thus considered unlikely to trigger counter-adaptations in herbivores (Rosenthal \& Kotanen, 1994).

Plants avoid being consumed by employing structural deterrents such as spines and thorns, biochemical compounds such as proanthocyanidins (condensed tannins) and internal constitutive defences such as lignin and cellulose, which also act as structural support. Lignin influences the physical toughness and digestibility of plants reducing intake rates (Jung \& Allen, 1995; Scogings et al., 2004; Shipley \& Spalinger, 1992). The structural deterrents are defined as spines when they are made of leaves and thorns when they are made of branches (Raven et al., 1999). Spines and thorns are the first line of defence against herbivores foraging on most woody plants in semi-arid savanna. They provide mechanical protection through injuring herbivores' mouths, digestive systems and other body parts. The presence of spines and thorns reduces the rate of herbivory by impeding stripping motions and forcing the herbivore to eat around the defence (Myers \& Bazely, 1991; Wilson \& Kerley, 2003a). Spinescent woody plants also have small leaves further reducing herbivore foraging efficiency since the reward received is seldom worth the time or energy needed to exploit it (Belovsky et al., 1991; Gowda, 1996). Plant spinescence increases with exposure to herbivory by large browsers as an induced defence (Milewski et al., 1991). Spines and thorns protect both leaves and axillary meristems (Gowda, 1996). Spine and thorn removal experiments have been carried out to demonstrate the protective value of these structures (Wilson \& Kerley, 2003b; Hanley et al., 2007). Milewski et al. (1991) reported 
the removal of Acacia drepanolobium thorns as causing a threefold increase in mammalian browsing of new foliage. Increased rates of herbivory by bushbucks (Tragelaphus scriptus) and boergoats (Capra hircus) was also reported following the removal of thorns from spinescent shrub species in the Eastern Cape region of South Africa (Wilson \& Kerley, 2003b).

Avoidance strategies also involve keeping most edible biomass beyond the reach of terrestrial herbivores. This means that the plant will have to survive herbivory before growing beyond the reach of the browsers. Woody plants growing in nutrient-rich environments are likely to grow above browsing height for most herbivores faster than trees in nutrient-poor environments, which will suffer browsing for a longer period (Danell et al., 1997). Woody plants growing in nutrient-poor environments have slow growth rates that limit their capacity to grow rapidly beyond the reach of most browsing mammals. They have developed strong defences for protection against herbivory (Coley et al., 1985; Teague, 1989; Borchard et al., 2011). Woody plants that grow in resource-rich environments often do not avoid herbivory, but develop tolerance traits to minimize the harmful effects of herbivory (Skarpe \& Hester, 2008).

Storage of carbohydrates reserves in woody stems or underground is also a kind of escape strategy. Plants may also escape herbivory by association with either less palatable or more palatable species, depending on the foraging pattern of the herbivore (Hjalten et al., 1993; Hester et al., 2006). When palatable plants gain protection from their unpalatable neighbours the phenomenon is referred to as associational defence (McNaughton, 1978; Hjalten et al., 1993). However, palatable plants are usually susceptible to attack when they occur in a patch with unpalatable neighbours, a situation referred to as neighbour contrast susceptibility (Bergvall et al., 2006).

Plants do not respond passively to damage by herbivory. The optimal defence hypothesis predicts increases in defences in direct response to herbivory (Rhoades, 1979). Herbivore attack leads to decreased acceptability and plant nutritional quality (Malecheck \& Provenza, 1983; Rhoades, 1985; Lundberg \& Astrom, 1990). Plant defences will either reduce consumption rates or reduce the ability of herbivores to digest material once consumed (Belovsky et al., 1991; Robbins, 1993). Plants damaged by herbivores prevent further damage through an increase in digestion inhibiting compounds such condensed tannins (Cooper \& Owen-Smith, 1985) and an increase in structural deterrents such as spines and thorns (Milewski et al., 1991). Some African woody species such as A. karroo have been shown to increase chemical defences following physical damage (Teague, 1989). Condensed tannins deter herbivory by giving plants an undesirable, astringent taste (Harborne, 1991; Bryant et al., 1992) or by reducing availability of protein and other nutrients (Robbins et al., 1987) through protecting plant cell walls from being degraded in the rumen of herbivores and inactivating digestive enzymes (Cooper \& Owen-Smith, 1985). Milewski et al. (1991) reported branches of African Acacia trees that had been browsed by large herbivores as producing longer thorns and a greater density of thorns than inaccessible branches on the same trees. Rohner \& Ward (1997) also reported intense herbivory of Acacia tortilis as 
increasing thorn length and density. Long thorns deter large herbivores by decreasing bite sizes and biting rates (Cooper \& Owen-Smith, 1986; Belovsky et al., 1991; Gowda, 1996). Teague (1989) suggested that young shoots of $A$. karroo relied on chemical defences because their thorns were soft and offered little structural deterrence to the herbivores.

Both avoidance and tolerance involves costs for the plant such as in the building and maintenance of stores of energy and nutrients as well as of dormant buds that can be activated following herbivory (Bilbrough \& Richards, 1993). Plant defences compete with growth and reproductive requirements for nitrogen and carbohydrate resources (Hanley et al., 2007). Owen-Smith \& Cooper (1987) reported fewer plants as investing in both chemical and structural anti-herbivore defences to reduce costs to growth and reproduction. Acacia tortilis is heavily defended by both chemical and structural defences (Rohner \& Ward, 1997; Sebata et al., 2011). Most Acacia species occur in areas of low fertility (Rohner \& Ward, 1997) and adapt to these conditions by slow growth rates and efficient use of available nutrients (Coley et al., 1985), which may explain the ability of $A$. tortilis to invest in both types of defence.

\section{Herbivore adaptations to plant defences}

Herbivores need to develop ways of counteracting plant defences in order to utilise woody plants as browse (Hanley et al., 2007). Herbivores that forage on spinescent plants have smaller mouthparts to deal with the intricate task of removing small leaves from between dense assemblages of spines and thorns (Belovsky et al., 1991). Most browsing animals have agile lips and tongues that allow them to select leaves and avoid thorns (Gordon and Illius, 1988). For example goats with their mobile and narrow muzzle, can manoeuvre their mouths more easily among thorns to pluck small leaves, making thorns less effective in reducing cropping rates (Shipley et al., 1999; Cooper \& Owen-Smith, 1986). Giraffe (Giraffa camelopardalis) foraging on spinescent Acacia trees is facilitated by the possession of a long flexible tongue (Hanley et al., 2007). Most ungulate herbivores in the semi-arid savanna where spinescence is most prevalent also have tough, leathery mouthparts, and nicitating eye membranes, both thought to be adaptations for coping with foraging on spinescent plants (Brown, 1960). Browsers foraging on spinescent plants may compensate for the reduced foraging efficiency by spending more time at plants of that species. Foraging on twig tips where growth is occurring and thorns are soft may also be adopted as a strategy to increase intake rates (Singer et al., 1994).

The evolution of a ruminant stomach can also be considered as an adaptation to plant defences since this allows the ungulates to digest fibrous plant material (Perez-Barberia et al., 2004). The ungulate stomach has symbiotic microorganisms and also releases cellulase enzymes which break down cellulose-rich cell wall fractions of plant material releasing volatile fatty acids that are immediately absorbed by the stomach (Hanley et al., 2007).

Some herbivores are able to develop behavioural and physiological counter adaptations against chemical plant defences (Iason \& Villalba, 2006). For example, browsers such as goats secrete tannin-binding salivary proteins which counter the digestibility-reducing effect of ingested condensed tannins (Robbins et al., 1987). Tannin-binding salivary proteins 
contain a high proportion of proline, and proline-rich salivary proteins have a greater binding affinity for tannins than other proteins, and thus act to prevent tannins from interacting with other proteins in mammalian digestive systems (Shimada, 2006). The production of proline-rich proteins enhances cell wall (fiber) digestion of high-tannin forages by ungulates (Robbins et al., 1987).

\section{Browse instantaneous intake rates}

The foraging efficiency of browsers on different woody species can be defined in terms of the instantaneous intake rate (Wilson \& Kerley, 2003b). Browse instantaneous intake rate is a product of bite size and bite rate and is influenced by plant characteristics. Different browse species will allow browsers to crop varying number and size of bites leading to highly variable instantaneous intake rates. Illius \& Gordon (1990) estimated that browsers crop between 10000 and 40000 bites per day from different individual plants. Decisions made by the browser when selecting a bite have important consequences for its nutritional intake and hence fitness (Shipley et al., 1999). Most woody plants with nutritious forage have thorns or spines (Wilson \& Kerley, 2003b). In semi-arid and arid African savannas thorny plants occur in areas with many large browsers (Grubb, 1992). Plant characteristics such as leaf size, thorn density and inter-thorn spacing (leaf accessibility) affect instantaneous intake rates through their effects on bite size and bite rate (See Table 1).

\begin{tabular}{|c|c|c|c|c|}
\hline & $r$ & $r^{2}$ & Regression equation & \\
\hline \multicolumn{5}{|l|}{ a) Intake rate $v s$} \\
\hline Bite size & 0.89 & 0.79 & $y=0.04+0.02 x$ & $* *$ \\
\hline Bite rate & 0.76 & 0.58 & $y=20.87+3.02 x$ & $* *$ \\
\hline \multicolumn{5}{|l|}{ b) LAIN vs } \\
\hline Bite rate & 0.70 & 0.49 & $y=36.09+7.35 x$ & $* *$ \\
\hline Bite size & 0.45 & 0.20 & $y=0.14+0.03 x$ & $* *$ \\
\hline Intake rate & 0.62 & 0.38 & $y=4.97+1.63 x$ & $* *$ \\
\hline \multicolumn{5}{|c|}{ c) Thorn density $v s$} \\
\hline Bite size & -0.57 & 0.33 & $y=0.12-0.03 x$ & * \\
\hline Bite rate & -0.66 & 0.43 & $y=31.79-6.42 x$ & * \\
\hline Intake rate & -0.69 & 0.48 & $y=3.86-1.70 x$ & ** \\
\hline \multicolumn{5}{|l|}{ d) Leaf size $v s$} \\
\hline Intake rate & 0.73 & 0.53 & $y=0.87+0.20 x$ & $* *$ \\
\hline Bite size & 0.60 & 0.36 & $y=0.05+0.05 x$ & * \\
\hline Bite rate & 0.51 & 0.26 & $y=22.2+7.13 x$ & ns \\
\hline
\end{tabular}

ns - not significant, ${ }^{*}<0.05,{ }^{* *}<0.01$. Source: Sebata \& Ndlovu, 2010.

Table 1. Relationships $(y=a+b x)$ of intake rates, leaf accessibility indices (LAIN), thorndensity and leaf size (y) of five woody species in a semi-arid southern African savanna and various browse intake rate parameters $(\mathrm{x})$ achieved by goats when browsing on these plants $(n=14)$ 
To achieve higher instantaneous intake rates browsers have to select browse species that allow large bite sizes and higher bite rates. Thus factors that constrain both bite size and bite rate will reduce instantaneous intake rates. Leaf accessibility and leaf size positively influenced bite size while thorn density had a negative effect (Table 1). Species with higher leaf accessibility allowed higher bite rates as the goats could easily maneuver their mouths between thorns when plucking the leaves. Thorns restricted goat muzzle movement slowing down the rate of browse harvesting (Belovsky et al., 1991). Thorns also force browsers to change foraging strategy from twig biting and leaf stripping to the less detrimental picking of leaves from between the thorns (Cooper \& Owen-Smith, 1986; Gowda, 1996), reducing the loss of foliage to mammalian browsers. Browsers will achieve higher instantaneous intake rates through selecting species with higher leaf accessibility and larger leaves. However, handling time increases with increasing leaf size, suggesting that there is an optimum leaf size (Wilson \& Kerley, 2003a).

\section{Relationship between shoot morphology and herbivory}

Shoot morphology has an influence on how plants protect themselves against loss of valuable nutrients and photosynthetic tissue to herbivores (Sebata \& Ndlovu, 2012). Scogings et al. (2004) reported defences as being distributed among woody plants in semiarid savannas according to shoot morphology because it affects the vulnerability of plant parts to browsers. Woody plants can be divided into two groups viz. those that produce all their new leaves on new long shoots (shoot-dominated species) and those that produce most of their new leaves in clusters on short shoots at the nodes of old unbrowsable branches (shoot-limited species) (Scogings et al., 2004). Shoot-dominated species depend on active apical buds to extend internodes and add new leaf area and should thus have higher concentrations of nutrients than shoot-limited species which simply add new leaf area without shoot elongation (Ganqa \& Scogings, 2007; Scogings et al., 2004). Shoot-dominated species have more browseable shoots than shoot-limited species. Shoot-limited species tend to result in high bite rates and reduced instantaneous intake rates, while shoot-dominated species allow bigger bite sizes and relatively high instantaneous intake rates (Dziba et al., 2003). The apical meristems of shoot-dominated species are more vulnerable to herbivores than those of shootlimited species (Dziba et al., 2003) and thus require better anti-herbivory defences (Rhoades, 1979). Plants and plant parts exposed to herbivores are expected to be better chemically defended than those protected by structural deterrents (Cooper \& Owen-Smith, 1985). Goats have been shown to prefer shoot-limited over shoot-dominated species (See Figure 4).

The shoot-limited species are poorly defended chemically and depend on structural defences (thorns) which the goats are able to avoid using their mobile upper lips. Shootlimited species have lower contents of plant secondary compounds (condensed tannins and fibre) and higher digestibility and rumen fermentation than shoot-limited species (Sebata \& Ndlovu, 2012). Fibre enhances leaf toughness and reduces browsing (Jung \& Allen, 1995; Shipley \& Spalinger, 1992). Shoot-limited species also rapidly replace lost tissues through regrowth (Scogings et al., 2004). Shoot-limited and shoot-dominated species are able to adapt different anti-herbivory defences. 


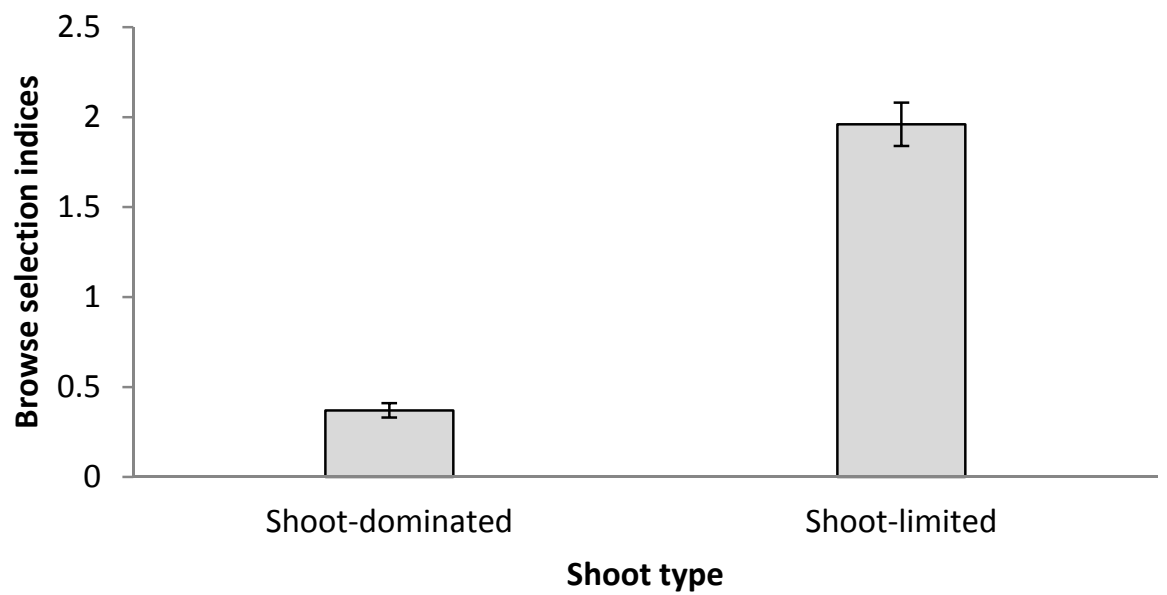

Figure 4. Browse selection indices of shoot-dominated and shoot-limited species in a semi-arid savanna ecosystem. Source: Sebata \& Ndlovu 2012

\section{Conclusion}

Woody plants, at light stocking rates, are able to compensate biomass lost to herbivory. However, at high animal densities they may not be able to replace lost foliage, which could eventually lead to their mortality. Thus to maintain a positive herbivore-plant relationship ungulate populations in savanna ecosystems need to be regulated. Although herbivory stimulates woody plant resprouting, there is still need for defences against excessive defoliation. However, plant defences compete with growth needs requiring a balance in resource allocation. The allocation of nutrients and water resources to defence and growth is poorly understood necessitating further studies. The most effective herbivore adaptation to plant defences is selection of browse with low physical and chemical defences e.g. selecting shoot-limited over shoot-dominated woody species. The extent to which herbivore adaptations to plant defences allow ungulates to exploit the diverse woody plant resources needs to be studied. Woody plants in semi-arid savanna ecosystems are able to persist under intense herbivory due to key adaptations that include structural defences, chemical defences and compensatory growth abilities of the plants. The relationship between plant defences and high compensatory growth abilities of the plants are poorly understood. Structural defences are effective in limiting foliage loss to browsers and represent a cheap form of defence in semi-arid savannas.

\section{Author details}

Allan Sebata

Department of Forest Resources \& Wildlife Management, National University of Science \& Technology (NUST), Ascot, Bulawayo, Zimbabwe 


\section{References}

Belovsky, G.E.; Schmitz, O.J.; Slade, J.B. \& Dawson, T.J. (1991). Effects of spines and thorns on Australian arid zone herbivores of different body masses. Oecologia 88: 521-528.

Belsky, A.J. (1986). Does herbivory benefit plants? A review of the evidence. American Naturalist, 127: 870-892.

Bergström, R. \& Danell, K. (1987). Effects of simulated browsing by moose on morphology and biomass of two birch species. Journal of Ecology 75: 533-544.

Bergstrom, R.; Skarpe, C. \& Danell, K. (2000). Plant responses and herbivory following simulated browsing and stem cutting of Combretum apiculatum. Journal of Vegetation Science 11: 409-414.

Bergvall, U.A.; Rautio, P.; Kesti, K.; Tuomi, J. \& Leimar, O. (2006). Associational effects of plant defences in relation to within and between-patch food choice by a mammalian herbivore: neighbour contrast susceptibility and defence. Oecologia 147: 253-260.

Bilbrough, C.J. \& Richards, J.H. (1993). Growth of sagebrush and bitterbrush following simulated winter browsing: mechanisms of tolerance. Ecology 74:481-492.

Birkett, A. \& Stevens-Wood, B. (2005). Effects of low rainfall and browsing by large herbivores on an enclosed savannah habitat in Kenya. African Journal of Ecology 43:123-130.

Bond, W.J. \& Midgley, J.J. (2001). Ecology of sprouting in woody plants: the persistence niche. Trends in Ecological Evolution 16: 45-51.

Borchard, F.; Berger, H.; Bunzel-Drüke, M. \& Fartmann, T. (2011). Diversity of plant-animal interactions: Possibilities for a new plant defense indicator value? Ecological Indicators 11: 1311-1318.

Bowyer, J.W. \& Bowyer, R.T. (1997). Effects of previous browsing on the selection of willow stems by Alaskan moose. Alces 33: 11-18.

Brown, G.D. (1960). Ants, acacias and browsing mammals. Ecology 41: 587-592.

Bryant, J.P.; Reichardt, P.B. \& Clausen, T.P. (1992). Chemically mediated interactions between woody plants and browsing mammals. Journal of Range Management 45:18-24.

Coley, P.D.; Bryant, J.P. \& Chapin, F.S. (1985). Resource availability and plant antiherbivore defence. Science 230: 895-899.

Cooper, S.M. \& Owen-Smith, N. (1985). Condensed tannins deter feeding by browsing ruminants in a South-African savanna. Oecologia 67: 142-146.

Cooper, S.M. \& Owen-Smith, N. (1986). Effects of plant spinescence on large mammalian herbivores. Oecologia 68: 446-455.

Cornell, H.V. \& Hawkins, B.A. (2003). Herbivore responses to plant secondary compounds: a test of phytochemical coevolution theory. American Naturalist 161:507-522.

Crawley, M.J. (1983). Herbivory: the dynamics of animal-plant interactions. Blackwell Scientific publications, Oxford.

Crawley, M.J. (1997). Plant ecology. Blackwell Scientific publications, Oxford.

Dahl, B.E. \& Hyder, D.N. (1977). Developmental morphology and management implications. In: Sosebee, R.E. (Ed.), Rangeland plant physiology. Society for Range Management. Denver, Colorado.

Danell, K.; Bergstrom, R. \& Edenius, L. (1994). Effects of large mammalian browsers on architecture, biomass, and nutrients of woody plants. Journal of Mammalogy 75: 833-844. 
Danell, K.; Haukioja, E. \& Huss-Danell, K. (1997). Morphological and chemical responses of mountain birch leaves and shoots to winter browsing along a gradient of plant productivity. Ecoscience 4: 296-303.

Dangerfield, J.M. \& Modukanele, B. (1996). Overcompensation by Acacia erubescens in response to simulated browsing. Journal of Tropical Ecology 12: 905-908.

Dube, S.; Mlambo, D. \&Sebata, A. (2009). Response of Faidherbia albida (Del.) A. Chev., Acacia nigrescens Oliver. and Acacia nilotica (L.) Willd ex Del. seedlings to simulated cotyledon and shoot herbivory in a semi-arid savanna in Zimbabwe. African Journal of Ecology 48: 361-367.

Du Toit, J.T. (2003). Large herbivores and savanna heterogeneity. In: Du Toit, J.T., Rogers, K.H., Biggs, H.C. (Eds.), The Kruger Experience: Ecology and Management of Savanna Heterogeneity. Island Press, Washington, DC, pp. 292-309.

Du Toit, J.T.; Bryant, J.P. \& Frisby, K. (1990). Regrowth and palatability of Acacia shoots following pruning by African Savanna browsers. Ecology 71: 140-154.

Dziba, L.E.; Scogings, P.F.; Gordon, I.J. \& Raats, J.G. (2003). Effects of season and breed on browse species intake rates and diet selection by goats in the False Thornveld of the Eastern Cape, South Africa. Small Ruminant Research 47: 17-30.

Fornara, D.A. \& du Toit, J.T. (2008). Community-level interactions between ungulate browsers and woody plants in an African savanna dominated by palatable-spinescent Acacia trees. Journal of Arid Environments 72: 534-545.

Ganqa, N.M. \& Scogings, P.F. (2007). Forage quality, twig diameter, and growth habit of woody plants browsed by black rhinoceros in semi-arid sub-tropical thicket, South Africa. Journal of Arid Environment 70: 514-526.

Goheen, J.R.; Young, T.P.; Keesing, F. \& Palmer, T.M. (2007). Consequences of herbivory by native ungulates for the reproduction of a savanna tree. Journal of Ecology 95:129-138.

Gordon, I.J. \& Illius, A.W. (1988). Incisor arcade structure and diet selection in ruminants. Functional Ecology 2: 15-22.

Gowda, J.H., 1996. Spines of Acacia tortilis: what do they defend and how? Oikos 77: 279-284.

Grubb, P.J. (1992). A positive distrust in simplicity - lessons from plant defences and from competition among plants and among animals. Journal of Ecology 80: 585-610.

Hanley, M.E.; Lamont, B.B.; Fairbanks, M.M. \& Rafferty, C.M. (2007). Plant structural traits and their role in anti-herbivore defence. Perspectives in Plant Ecology, Evolution and Systematics 8: 157-178.

Harborne, J.B. (1991). The chemical basis of plant defence. In: Palo, R.T., Robbins, C.T. (Eds.), Plant Defences against Mammalian Herbivory. CRC Press, Boca Raton, FL, pp. 192.

Hartley, S.E. \& Jones, C.G. (1997). Plant chemistry and herbivory, or why is the World green? In: Crawley, M.J. (Ed.), Plant Ecology. Blackwell, Oxford, pp. 284-324.

Hester, A.J.; Bergman, M.; Iason, G.R. \& Moen, R. (2006). Impacts of large herbivores on plant community structure and dynamics. In: Danell, K., Bergstrom, R., Duncan, P., Pastor, J. (eds) Large herbivore ecology and ecosystem dynamics. Cambridge University Press, Cambridge, pp 97-141.

Hjalten, J., Danell, K. \& Lundberg, P. (1993). Herbivore avoidance by association - vole and hare utilization of woody plants. Oikos 68: 125-131. 
Iason, G.R. \& Villalba, J.J. (2006). Behavioural strategies of mammal herbivores against plant secondary metabolities: the avoidance-tolerance continuum. Journal of Chemical Ecology 32: $1115-1132$.

Illius, A.W. \& Gordon, I.J. (1990). Constraints on diet selection and foraging behavior in mammalian herbivores. In: Hughes, R.E. (Ed.), Behavioural Mechanisms of Food Selection. Springer, Berlin, Germany, pp. 369-393.

Jung, H.G. \& Allen, M.S. (1995). Characteristics of plant cell walls affecting intake and digestibility of forages by ruminants. Journal of Animal Science 73: 2774-2790.

Lundberg, P. \& Astrom, M. (1990). Low nutritive quality as a defence against optimally foraging herbivores. American Naturalist 135: 547-561.

Makhabu, S.W. \& Skarpe, C. (2006). Rebrowsing by elephants three years after simulated browsing on five woody plant species in northern Botswana. South African Journal of Wildlife Research 36:99-102.

Makhabu, S.W; Skarpe, C. \& Hytteborn, H. (2006). Elephant impact on shoot distribution on trees and on rebrowsing by smaller browsers. Acta Oecologia. 30:136-146.

Malecheck, J.C. \& Provenza, F.D. (1983). Feeding behaviour and nutrition of goats on rangelands. World Annual Review 3: 38-48.

Maschinski, J. \& Whitham, T.G. (1989). The continuum of plant responses to herbivory: the influence of plant association, nutrient availability, and timing. American Naturalist, 134:1-19.

McNaughton, S.J. (1978). Serengeti ungulates: feeding selectivity influences the effectiveness of plant defence guilds. Science 199: 806-807.

McNaughton, S.J. (1979). Grazing as an optimization process: grass-ungulate relationships in the Serengeti. American Naturalist, 113: 691-703.

Mekuria, A.; Demel, T. \& Mats, O. (1999). Soil seed flora, germination and regeneration pattern of woody species in Acacia woodland of the Rift Valley in Ethiopia. Journal of Arid Environments 43: 411-435.

Milewski, A.V.; Young, T.P. \& Madden, D. (1991). Thorns as induced defences: experimental evidence. Oecologia 86: 70-75.

Mwalyosi, R.B.B. (1990). The dynamic ecology of Acacia tortilis woodland in Lake Manyara National Park, Tanzania. African Journal of Ecology 28: 189-199.

Myers, J.H. \& Bazeley, D. (1991). Thorns, spines, prickles and hairs: are they stimulated by herbivory and do they deter herbivores? In: Tallamyr, D.J., Raup, M.J. (eds) Phytochemical induction by herbivores. Academic Press, New York, pp 326-343.

Noumi, Z.; Touzard, B.; Michalet, R. \& Chaieb, M. (2010). The effects of browsing on the structure of Acacia tortilis (Forssk.) Hayne ssp. raddiana (Savi) Brenan along a gradient of water availability in arid zones of Tunisia. Journal of Arid Environments 74, 625-631.

Nyengera, R. \& Sebata, A. (2009). Effect of eland density and foraging on Combretum apiculatum physiognomy in a semi-arid savannah. African Journal of Ecology, 48:45-50

Owen-Smith, N. \& Cooper, S.M. (1987). Palatability of woody plants to browsing ruminants in a South African savanna. Ecology 68: 319-331.

Page, K.N. \& Whitham, T.G. (1987). Overcompensation in response to mammalian herbivory: the advantage of being eaten. American Naturalist 129: 407-416. 
Perez-Barberia, F.J.; Elston, D.A.; Gordon, I.J. \& Illius, A.W. (2004). The evolution of phylogenetic differences in the efficiency of digestion in ruminants. Proceedings of the Royal Society. London Series B 271: 1081-1090.

Raven, P.H.; Evert, R.F. \& Eichhorn, S.E. (1999). Biology of Plants, sixth ed. W. H. Freeman and Company, New York.

Rhoades, D.F. (1979). Evolution of plant chemical defence against herbivores. In: Rosenthal, G.A., Janzen, D.H. (Eds.), Herbivores: Their Interaction with Secondary Plant Metabolites. Academic Press, Orlando, pp. 3-54.

Rhoades, D.F. (1985). Offensive-defensive interactions between herbivores and plants: Their relevance in herbivore population dynamics and ecological theory. American Naturalist 125: 205-238.

Robbins, C.T. (1993). Wildlife Feeding and Nutrition. Academic Press, San Diego.

Robbins, C.T.; Mole, S.; Hagerman, A.E. \& Hanley, T.A. (1987). Role of tannins in defending plants against ruminants: reduction in dry matter digestion. Ecology 68: 1606-1615.

Rohner, C. \& Ward, D. (1997). Chemical and mechanical defence against herbivory in two sympatric species of desert Acacia. Journal of Vegetation Science 8: 717-726.

Rooke, T.; Bergstrom, R.; Skarpe, C. \& Danell, K. (2004). Morphological responses of woody species to simulated twig-browsing in Botswana. Journal of Tropical Ecology 20: 281-289.

Rosenthal, G.A. \& Janzen, D.H. (1979). Herbivores: Their Interaction with Secondary Plant Metabolites. Academic Press, New York.

Rosenthal, J.P. \& Kotanen, P.M. (1994). Terrestrial plant tolerance to herbivory. Trends in Ecological Evolution 9: 145-148.

Scholes, R.J. (1997). Savanna. In: Cowling, R.M., Richardson, D.M., Pierce, S.M. (Eds.), Vegetation of Southern Africa. Cambridge University Press, Cambridge, pp. 258-277.

Scogings, P.F. (2003). Impacts of ruminants on woody plants in African savannas: an overview. In: Allsopp, N., Palmer, A.R., Milton, S.J., Kirkman, K.P., Kerley, G.I.H., Hurt, C.R., Brown, C.J. (Eds.), Rangelands in the New Millenium. VII International Rangeland Congress, Durban, South Africa, pp. 955-957.

Scogings, P.F. \& Mopipi, K. (2008). Effects of water, grass and $\mathrm{N}$ on responses of Acacia karroo seedlings to early wet season simulated browsing: Aboveground growth and biomass allocation. Journal of Arid Environments 72:509-522.

Scogings, P.F.; Dziba, L.E. \& Gordon, I.J. (2004). Leaf chemistry of woody plants in relation to season, canopy retention and goat browsing in a semiarid subtropical savanna. Austral Ecology 29: 278-286.

Sebata, A. \& Ndlovu, L.R. (2010). Effect of leaf size, thorn density and leaf accessibility on instantaneous intake rates of five woody species browsed by Matebele goats (Capra hircus L) in a semi-arid savanna, Zimbabwe. Journal of Arid Environment 74: 1281-1286.

Sebata, A. \& Ndlovu, L.R. (2012). Effect of shoot morphology on browse selection by free ranging goats in a semi-arid savanna. Livestock Science 144: 96-102.

Sebata, A.; Nyathi, P. \& Mlambo, D. (2009). Growth responses of Grewia flavescens Juss. (Sandpaper Raisin) and Grewia monticola Sond. (Grey Grewia) (Tiliaceae) to shoot clipping in a semi-arid Southern African savanna. African Journal of Ecology 47: 794-796.

Sebata, A.; Ndlovu, L.R. \& Dube, J.S. (2011). Chemical composition, in vitro dry matter digestibility and in vitro gas production of five woody species browsed by Matebele 
goats (Capra hircus L.) in a semi-arid savanna, Zimbabwe. Animal Feed Science and Technology 170: 122- 125.

Shimada, T. (2006). Salivary proteins as a defence against dietary tannins. Journal of Chemical Ecology 32:1149-1163.

Shipley, L.A. \& Spalinger, D.E. (1992). Mechanisms of browsing in dense food patches: effects of plant and animal morphology on intake rate. Canadian Journal of Zoology 70:1743-1752.

Shipley, L.A.; Illius, A.W.; Danell, K.; Hobbs, N.T. \& Spalinger, D.E. (1999). Predicting bite size selection of mammalian herbivores: a test of a general model of diet optimization. Oikos 84: 55-68.

Singer, F.J.; Mark, L.C. \& Cates, R.C. (1994). Ungulate herbivory of willows on Yellowstone's northern winter range. Journal of Range Management 47: 435-443.

Skarpe, C. (1990). Shrub layer dynamics under different behaviors density in arid savannas, Botswana. Journal of Applied Ecology 27: 873-885.

Skarpe, C. (1992). Dynamics of savanna ecosystems. Journal of Vegetation Science 3:293-300.

Skarpe, C. \& Hester, A. (2008). Plant traits, browsing and grazing herbivores, and vegetation dynamics. In: Gordon, I.J., Prins, H.H.T. (eds) The ecology of browsing and grazing. Springer-Verlag Berlin Heidelberg. pp 217-261.

Strauss, S.Y. \& Agrawal, A.A. (1999). The ecology and evolution of plant tolerance to herbivory. Trends in Ecological Evolution 14: 179-185.

Teague, W.R. (1989). Patterns of selection of Acacia karroo by goats and changes in tannin levels and in vitro digestibility following defoliation. Journal of the Grassland Society of Southern Africa 6: 230-235.

Teague, W.R. \& Walker, B.H. (1988). Effect of intensity of defoliation by goats at different phenophases on leaf and shoot growth of Acacia karroo Hayne. Journal of the Grassland Society of Southern Africa 5: 197-206.

Trlica, M.J. \& Singh, J.S. (1979). Translocation of assimilates and creation, distribution and utilization of reserves. In: Goodall, D.W., Perry, R.A. (Eds.), Arid land ecosystems: structure, functioning and management. Cambridge University Press.

Tsumele, J., Mlambo, D., Sebata, A. (2009). Responses of three Acacia species to simulated herbivory in a semi-arid southern African savanna. African Journal of Ecology 45: 324-326.

Walker, B.H. (1985). Structure and function of savannas: an overview. In: Tothill, J.C., Mott, J.J. (Eds.), Ecology and Management of the World's Savannas. Australian Academy of Science and CAB, Farnham Royal, Canberra, pp. 83-91.

Wilson, S.L. \& Kerley, G.I.H. (2003a). Bite diameter selection by thicket browsers: the effect of body size and plant morphology on forage intake and quality. Forest Ecology and Management 181: 51-65.

Wilson, S.L., Kerley, G.I.H. (2003b). The effect of plant spinescence on the foraging efficiency of bushbuck and boergoats: browsers of similar body size. Journal of Arid Environments 55: 150-158. 